\title{
Death and Dying Between Anthroposophy and Biomedicine
}

| ${ }^{1}$ Raquel Littério de Bastos, ${ }^{2}$ Regina Yoshie Matsue, ${ }^{3}$ Pedro Paulo Gomes Pereira I

Abstract: Death and dying constantly provoke debates regarding boundaries, rules and disputes for the legitimacy of different meanings regarding processes of finalizing life. This article places special emphasis on conflicts between the therapeutic system of anthroposophy and biomedicine in Brazil. The reflections contained in the text are based on ethnographic research, carried out in multiple locations between 2012 and 2015, investigating concepts of cure in anthroposophy in three different communities: two in Brazil, and one in Switzerland. Over the course of this journey, our experience as ethnographers led us to reflect on death and dying among the Widows of Demétria, one of the anthroposophical communities in which we conducted our research. Demétria is a rural neighborhood located in the city of Botucatu, in the interior of São Paulo state. The community was first organized during the 1970s, and it consists mostly of women - both Europeans and Brazilians - who live together, sharing a lifestyle that reimagines the ethos of death as a part of the aesthetic project of Bildung, which differs significantly from the conception of the death process in biomedicine.

> Keywords: Death; Anthroposophy; Biomedicine; Bildung; Aesthetics.

\author{
${ }^{1}$ Universidade Federal do Rio \\ Grande do Norte. Natal-RN, Brazil \\ (raquelitterio@gmail.com). \\ ORCID: 0000-0002-7556-7701 \\ ${ }^{2}$ Departamento de Medicina \\ Preventiva, Universidade Federal \\ de São Paulo. São Paulo-SP, \\ Brazil (rymatsue08@yahoo.com). \\ ORCID: 0000-0001-5552-7051 \\ ${ }^{3}$ Departamento de Medicina \\ Preventiva, Universidade Federal \\ de São Paulo. São Paulo-SP, Brazil \\ (pedropaulopereira@gmail.com). \\ ORCID: 0000-0002-0298-2138
}

Received: 25/08/2019

Approved: 07/03/2020

Revised: 26/07/2021 


\section{Introduction}

Death and dying constantly provoke debates regarding boundaries, rules and disputes for the legitimacy of different meanings regarding processes of finalizing life. This article places special emphasis on conflicts between anthroposophy (a spiritual science elaborated in Switzerland at the beginning of the $20^{\text {th }}$ century that led to the founding of a therapeutic system) and biomedicine in Brazil. The reflections contained in the text are based on ethnographic research carried out in multiple locations between 2012 and 2015, investigating concepts of cure in anthroposophy in three different communities: two in Brazil, and one in Switzerland. Over the course of this journey, our experience as ethnographers led us to reflect on death and dying among the widows of Demétria, one of the anthroposophical communities in which we conducted our research. ${ }^{1}$

Demétria is a rural neighborhood located in the city of Botucatu, in the interior of São Paulo state. The community was first organized during the 1970s, and it consists mostly of women - both Europeans and Brazilians - who live together, sharing a lifestyle based on cultivating Bildung, a concept-word derived from German romanticism that expresses the process of cultural formation and the sense of German personhood (DUARTE, 2003), as well as processes of personal, spiritual and aesthetic development. Bildung presents an atemporal version of the world, and it is considered to be among the most important concepts of the eighteenth century.

The rules and taboos surrounding death and dying have led to rich, recurring investigations in the fields of social sciences and health. Already in 1921, Marcel Mauss wrote an essential text on the necessary expression of feelings. Anthropological studies of death by Hertz (1978), Mauss (2003), and Thomas (1993) indicate the collective constitution of this system of orientation regarding death. Hertz, meanwhile, carried out a study of practices and beliefs regarding death, focusing on dual exequies to show that death cannot only be understood as a physiological and emotional phenomenon, but must also be seen as a process of rupture confronted by a social group.

Anthropological production relating to this theme shows that death cannot be understood only as an occurrence, inasmuch as it is a process (LYRA, 2017; MENEZES, 2013; MENEZES; GOMES, 2011). A great deal of research involves the expressions "dignified death" or "death with dignity" (LADOUCEUR, 2017; GOLSE, 2016; KOVÁCS, 2014). Funerary rituals are also frequently cited 
in anthropological works (CARNEIRO, 2015), almost always accompanied by investigations of the emotional grammar utilized in rituals and in support groups for the terminally ill (KOVÁCS, 2014).

Among articles discussing the concept of brain death, we will highlight those that focus on the judicialization of death and on living wills (KAMIJO, 2016; PACHECO, 2016); on palliative care, death with dignity, or end-of-life bioethics (ALVES and CASAGRANDE, 2016); and on hospital death, prolonging life, and assisted death (WIEBE, 2018; TEIXEIRA, 2016). Additionally, certain articles explore the difficulties that healthcare professionals face in dealing with processes of death and dying (SILVA, HORTALE, 2006; COMBINATO, MARTIN, 2017).

In academic productions regarding death and dying, we have identified a growing body of work that address conflicts in practices relating to the dying process between other medical models of rationality and the biomedical model, especially between anthroposophy and biomedicine. Although the notion of conflict is impregnated with negative attributions, Georg Simmel breaks with this dichotomy, attributing an importance to conflict as a form of socialization in reciprocal action among people. Conflict may take on a unifying meaning, inasmuch as it is often what permits and makes possible coexistence with what would otherwise be intolerable.

The conception of death and of dying in anthroposophy was strongly influenced by German Romanticism and by Naturphilosophie, elaborating an ethos of death as a project of Bildung that differs from the conception of the process of death in biomedicine (BASTOS 2018). In addition to being a notion of a Germanic person, Bildung is also - for this cultural group - a theme of cure: it is a process of forging armor in order to confront life's adversities with courage and dignity. In the conflict generated by the unavoidable coexistence with biomedicine at the end of life, followers of anthroposophy reaffirm that one must learn to die in order to be reborn, as death is one of the stages of Bildung.

This text describes conflicts and strategies that followers of anthroposophy utilize so as to be able to exercise control in making decisions regarding death and dying while facing the biomedical model. Narratives of confrontations that the Widows of Demétria have experienced in this conflict make up the first part of the article, thereby preparing the reader for the strategies they develop to dealing with biomedical rules relating to the judicialization of death. The Widows of Demétria negotiate concepts of death, dying, and organ donation. 


\section{Methodological Progression}

The results presented in this article are based on a multi-site ethnography, carried out between 2012 and 2016, that aimed to investigate the conception of cure as a Bildung in anthroposophy. The research began in 2012 at Tobias Clinic, in the city of Sáo Paulo, where we participated in physical, spiritual, and soul-based therapies over the course of one year. In 2013, we spent six month registering community routines involving birth and death among residents of Demétria, a rural neighborhood in the city of Botucatu, São Paulo state. Finally, in 2014, we accompanied the daily lives of a community in the city of Vevey, in the French part of Switzerland, for six more months.

In 2013, all of our interlocutors were residents of Demétria with different degrees of adherence to anthroposophy. Their participation in the research took place on a voluntary basis through a network of relations in which one participant connected us to the next. Over the course of the entire investigation, we carried out participant-observer research, in addition to conducting interviews, and accompanying daily life in anthroposophicall communities so as to observe residents' routines.

For the article's specific critical reflections, we have availed ourselves of the results of the research conducted in Demétria, a rural neighborhood that, in 2013, was home to more than 600 inhabitants who were interested in or practiced anthroposophy, and who were surrounded by services connected to the spiritual science's philosophy, such as a Waldorf school, a Community of Christians, stores featuring organic and biodynamic products, bars, restaurants, and inns, as well as therapeutic clinics and other businesses related to growing and producing organic food.

On multiple occasions over the course of the ethnography, the discussion of death and dying arose. This was a recurring theme that led to spirited discussions, and about which people spoke of their expectations and fears. These narratives grew in quantity, revealing a diversity of situations in conflict with biomedicine. This was how we grew closer to the Widows of Demétria and the challenges that they faced in concretizing their desire to die in a manner different than that established by biomedicine. We will tell some of these stories below. 


\section{Results}

\section{The Widows of Demétria}

Our first encounter with the Widows of Demétria took place in 2013, while conducting our ethnographic research in the rural anthroposophical community in which they lived, in the city of Botucatu. Demétria is the first community in Latin America - in fact, the first outside of Europe - to implement biodynamic agriculture on a wide scale. The original impulse behind Demétria's founding was based on producing raw materials to meet the demands of the Weleda pharmaceutical corporation. Later, the community transformed into a rural neighborhood inhabited by followers of anthroposophy and those interested in the spiritual science. Demétria's inhabitants offer services that meet the needs of the anthroposophical community, such as a Waldorf School, a Community of Christians, therapeutic spaces, and inns, as well as other initiatives. The neighborhood's population is composed primarily of middle- and upper-class women with access to formal education who descend from immigrant families. The oldest women sport grey hair, giving them a higher social status compared to the rest. The community considers them to be wise women, and they are recognized for their physical health, which is attributed to biodynamic eating habits and the local production of organic food.

Over the course of six months, we participated in a group with women from Demétria's Christian community. Our relationship with these women of serene countenance allowed us to have further contact with situations of dying in accordance with the principles of anthroposophy. We had numerous conversations - some pleasant, and others quite difficult - all of which made it possible for us to understand anthroposophy's ethos regarding dying and funerary rituals. Most of all, these conversations exposed us to a different emotional grammar in relation to the experience of death, one that was very distinct from that with which we were raised; this, in turn, gave us an important exercise in alterity. Bastos notes that her father passed away in 2012, at the beginning of this research, which gave her a greater openness toward subjects relating to death. As the narratives of this ethnography developed, she envied these women's emotional control, and their determination in confronting the conflicts they faced in order to have their convictions respected, even though they were vulnerable to life's misfortunes. As she observes: 
When listening actively to stories about death and dying, pain brought us together. But uncontrolled crying distanced us, as did detours in emotional etiquette. There, in that community, people died struggling, but they did not struggle against death. There was no space for crying in this new rebirth. (BASTOS 2018, p. 148)

One specific Widow of Demétria called attention to the themes presented in the above quote. Ms. Melba - or, as everyone calls her affectionately, Mel - was the first participant in the women's group to make herself available to participate in our research. Almost 70 years old, this svelte gaúch $a^{2}$ had a long history as an activist in French and Brazilian peasant agricultural movements, in which she had fought for human rights. Later, after marrying a Frenchman, she became involved with organic and biodynamic agriculture through her husband's influence, after which both became acquainted with anthroposophy. According to Mel, her family's anarchist roots were responsible for her excellent critical sense. At meetings, or anywhere else in her presence, no one could make any dogmatic affirmations about anthroposophy without Mel quickly launching into an interminable debate of ideas. Her physical and emotional disposition for dialogue produced many interesting conversations, as well as a lasting friendship. But our most intense conversations were about her widowhood, and about her husband's sickness and death. For the purposes of this article, we recall the conversations in which she elucidated the struggles she had faced in opposing biomedical impositions during the dying process.

Mel's fearlessness in the face of sickness and death makes her story and that of her husband - like all of her narratives - a story of activism. In this case, she advocated for an honorable death, for their right to die according to their own conceptions.

\section{The Aesthetics of Death}

To me, [the people who advocate for] prolonging life are a mafia! It suits the interests of doctors and of hospitals. Hospitals pass the cost of "palliative care" between themselves. Morphine weakens the Self and causes us to lose consciousness. So my husband chose to bear the pain; he alone would decide when to take morphine. His goal was to bear the pain until he died, without morphine. But he couldn't bear it, and he asked the doctor for morphine. He told the doctor, "Now you can give me morphine, now that I only have three days left to live. I've said everything I wanted to say to my wife, I've written letters asking for forgiveness, everything is ready. (Mel)

With her extremely performative personality, Mel narrated this episode as though it were an opera. Changing her voice based on the moment she was retelling, she 
guided the researcher through her story, allowing her to understand how much energy each character had needed to expend in confronting adverse situations. In the saddest moments, and moments of great closeness between Mel and the researcher, Mel lowered the tone of her voice to a whisper. These moments were always followed by the slow movement of taking off her glasses, marking the need for silence before continuing. Immediately afterward, Mel would let out a shout, showing a change in the situation, a turning over, new data, or an outcome. Serene and determined, she did not shed a single tear during any of our encounters.

This is not to say that Mel's suffering did not exist. Her bent body and clenched fists showed her pain at remembering such sad situations. Yet there was something more that the researcher could not comprehend, especially because in the norms of the "obligatory expression of feelings" in which she was raised, crying is a habitual form of expressing pain publicly. Mel, however, showed no tears, no despair. She suffered, but her suffering was noble, aesthetic, and beautiful.

Followers of anthroposophy aim to control their reactions. Reacting to the world's provocations in an impetuous way weakens one's Self. Conscious of the difficulties of life, they aim to stand firm through their understanding that everything has a lesson to teach, and that everyone evolves in their own way. Based on these liberal convictions, they are more concerned with their own processes of development than with the stumbles of others. Their Bildung carries the ethics of not whining, because the effort of metamorphosizing oneself into something is more important than merely bearing pain. This is a personal battle in which the greatest enemy is the Self, dispersed in exaggerated emotions. The aesthetics of pain consists of biting one's own tail, as in the ouroboros, the cycle of evolution that returns into itself in a constant project of Bildung.

In anthroposophy, when sickness leads to death - in other words, at the end of sickness - death serves to benefit the evolution of that specific dying human being. Without sickness, humanity would not reach its evolutionary aims. Steiner (1998, p. 17) said: "Man sickens as he develops himself." Whether through cure or even through death, sickness longs to go beyond itself, and to elevate us to a higher level in life, between death and new birth, thereby healing human essence.

In its terminal phases, cancer demands a decision of whether or not to take morphine. Biomedicine, through the politics of palliative care, aims to avoid pain and suffering in terminal patients and their families. For biomedicine, analgesia 
provides a "good death," preserving human dignity. The use of morphine in cases of extreme pain is a consensus in biomedicine. Doctors are taught to care for life, whereas death is seen as a failure, a defeat (ALVES; CASAGRANDE, 2016, p. 2).

In anthroposophy, the use of morphine hinders the ability to "go beyond oneself," inasmuch as morphine causes patients to lose consciousness of their actions during the dying process. Maintaining consciousness, especially at the time of death, is considered ideal, the most desirable way to cross the threshold: conscious death is thought to be capable of "elevating us to a superior level of life."

According to anthroposophical cosmology, the use of opioids, or the constant use of any other analgesic during life, denotes an imbalance of spiritual forces, such that satanic forces are able to exert a greater influence. One of anthroposophy's orientations in order to maintain one's consciousness at the time of death - in spite of pain and suffering - is to practice meditation throughout one's life, so as to make use of it during difficult moments. Succumbing to morphine is not prohibited, but it weakens the attitude necessary to confront death.

However, anthroposophy does not explicitly prohibit the use of morphine or of any other analgesic, although it does alert members to the confusion that these may cause after death, thereby slowing spiritual evolution. Individuals treated with morphine will find themselves lost in the spiritual world, without knowing exactly what has happened. And without perceiving their passage over the threshold, they will wander for an indeterminate amount of time, until they receive spiritual guidance.

In order to avoid this undesirable situation, members of anthroposophy are advised to exercise their rights when choosing whether or not to accept specific medical treatments during times of sickness and hospitalization, or in terminal cases. A conflict exists between norms. When hospitalized, followers of anthroposophy feel vulnerable in defending their lifestyle, as though they were locked in an arm wrestling match with biomedicine, and whoever proves stronger will decide the Other's death.

Members of this spiritual science - especially the community of Christians who study Christology ${ }^{3}$ - consider the hospice model of death to be applicable to the anthroposophical vision of processes of death and dying, in which human beings find themselves on a path of spiritual evolution, and in which death may take on a central role in their destiny, as part of a process of internal cure. According to Floriani (2014), the hospice movement is centered on the person, unlike the reigning biomedical model, which is focuses its interventions on the disease. Formally 
speaking, the hospice model arose at the end of the 1970s, when St. Christopher's Hospice was founded in England. The word "hospice" derives from the Latin hospes, which originally meant host or innkeeper; in the fourth century, through differing uses in Christianity, it also came to mean a stranger, a guest, or a traveler.

The concept of a "good death" underlying the hospice movement is associated with patients' specific disposition to confront their sickness. This model of death is based on ancient societies, such as agricultural societies in which the social ritualization of death began and was organized on a communitarian basis, as well as in ethical and aesthetic elements of ancient Greece, especially Spartan society, which exalted virtuous disposition in confronting struggles (FLORIANI, 2014).

According to Vernant (1989), this heroic posture - which has also been identified and commented on by such celebrated Hellenists as Pierre Vidal-Nacquet and Paul Veyne - does not have any sort of utilitarian character, even in terms of a desire for social prestige. Instead, it is of a transcendental nature, relating to the human condition that the gods instilled in every mortal creature: following the height of one's youth, and facing the decline of one's strength and the decrepitude of old age both of which are inevitable - the ideal is to overcome death by accepting it, instead of suffering through it. True death, in this vision, is silence, forgetting, obscure indignity, and the absence of a reputation.

This ideal is not only inscribed within a specific type of death, but also in a specific way of dying struggle, of dying nobly, "sustained in a profound aesthetic conception of what is beautiful and noble running through this specific mode of dealing with death: a beautiful death, an ideal or exemplary death" (FLORIANI, 2014, p. 10); namely, in being recognized, held in high esteem, and honored; above all, in being glorified for an end that is admired by all. A hero who, with the glory he acquired by devoting his life to combat, inscribes his individual reality in a group's collective memory, "expresses through his biography that death, because it occurs, is unalterable.” (VERNANT,1989, p. 56).

In Brazil, this specific form of struggle against being defeated by death - even though we know we will die - is called kalotanásia. It is a struggle that, according to the followers of anthroposophy, is locked into the most profound instances of human nature, giving meaning and disposition to those who struggle and confront death. Theirs is not struggle against succumbing to death, but instead, of transcending it. In other words, it is not a struggle against death, but rather with death. This 
form of confrontation, considered virtuous, can take what misleadingly appears to be external resignation and cloak it in an internal, extreme disposition of courage within a context of struggle for what comes beyond death. (FLORIANI, 2014)

This anthroposophical cosmovision is expressed clearly by our interlocutors, who understand death as a passage or a transition to a form of existence that is different than sensorial life. Disease, especially when incurable, is understood as offering possibilities of transcendence, transformation, and spiritual growth - in spite of its progression - which is always linked to the life of the sick person. From this perspective, physical sickness is seen as offering help to patients who, by confronting their existential condition through the social ritualization of their processes of death, can - depending on the circumstances of each individual case - be guided and tended to in their passage over the threshold. Thus, patients can be tended to in processes of internal transformation, in a sort of sowing of what lies beyond death.

To summarize: behind various characterizations of what constitutes the "good death" defended by the hospice movement, and shared by anthroposophical therapies, we find a death that is both aesthetically perceived and ethically desirable; in other words, a model of death considered beautiful and dignified. Marie de Hennezel (2005) interprets this model of death as a subjective labor exercised by the "die-r," the "labor of passing away." According to Hennezel, this "labor of passing away" is a final effort in constructing a process of "entering alive into one's death." In other words, it is a conclusion and elaboration of life and of death.

[Having] a wake that lasts several days depends on the cleverness of the priest, and of the person taking care of the wake. For example, my husband died in the early morning, and that's how cleverness works: in my husband's case, I knew that if I said that he had died at 8 in the morning, they would certainly want to bury him that same afternoon. And because we believe that the longer we wait for burial, the better, in order for the spirit to leave the ethereal body, this is what I did at the hospital: I said, I want to accompany the preparation of the body, first I'm going to accompany everything that you do. I want to stay here longer, I just want to be alone. I'm the responsible party, I decide. I didn't give an explanation. Then the community's priest arrived, and even though I was under pressure, I didn't care about the hospital, I kept stalling things until the end of the afternoon. I already knew that the funeral home closed at $5 \mathrm{pm}$, so by the time I arrived there, it was too hire their services. The next morning, I made the excuse that we were still waiting for someone to arrive, and that they would only get there at $5 \mathrm{pm}$. The priest helped me stall everything he could. Unfortunately I couldn't keep it going for three whole days, the most I could do was to annoy them a lot. By the time we made it to the cemetery in Vila Alpina, I had managed to stall, so that he was cremated after three days. (Mel) 
For Mel, cleverness in this conflict might be, for example, referring to anthroposophical medicine as "homeopathy" when a patient needs medicine. Although homeopathy has a subaltern status, it carries a degree of legitimacy, or else it is understood as not posing any threat to the hegemonic power of biomedicine. This cleverness also appears in stories about the process of holding wakes, all of which indicate a network of personal relations that seek to collaborate - whether based on affection for anthroposophy or respect for the people involved - so as to discover gaps in the system. In this way, a wake can proceed as closely as possible to the three days prescribed by the precepts of anthroposophy.

\section{The judicialization of death}

The lawyer advised us to be people, rather than patients. In other words, we shouldn't accept treatments passively. In order to have our wishes respected, the lawyer advised us to have various copies [of a living will], with various people accompanying the treatment and filling in for each other, so that someone documenting things would always be at the patient's side. I want this, this, and this, and if it doesn't happen, call the lawyer, and sue the doctor and the hospital. It has to be that way, otherwise they don't respect you. The story of my husband's sickness is the story of butting heads so that anthroposophy would be respected. Our biggest conflict was with the hospital director, so that two other doctors - who are friends of ours and followers of anthroposophy - could accompany his treatment. Sometimes they referred to anthroposophy as "homeopathy" so that they could treat him. We had to use the influence of our friends in order to use anthroposophical medicines in the hospital. (Mel).

We note here the episode related by Mel occurred ten or eleven years before the above interview, which took place in 2013. At that time, anthroposophical medicine had not yet been classified as medically rational in Brazil (ABMA, 2006). The judicial appeals process, which today is utilized to guarantee rights in the case of special treatments, also cannot entirely confront the power of biomedicine, especially in terms of deciding courses of treatment and - consequently - processes of dying. When Mel says, "In order to have our wishes respected, the lawyer advised us to have various copies [of a living will], with various people accompanying the treatment and filling in for each other so that someone documenting things would always be at the patient's side. I want this, this, and this, and if it doesn't happen, call the lawyer, and sue the doctor and the hospital," she demonstrates the anthroposophical community's fragility in having their conceptions of dying honored. In this case, even with documentation in hand, Mel and her husband required full-time 
observation. Here, the lawyer's presence was like that of a guardian of dying with "magical" legal powers, the only person capable of containing biomedicine's power over the process of dying.

So-called living wills originated in the United States in 1969, where they were established as documents that conferred the right to refuse medical treatment aimed at extending life in cases of terminal diagnoses or persistent "vegetative" states (DADALTO, 2013). According to Kamijo (2016), although healthcare professionals accept them, the practical application of living wills is impeded by the fact that they are little known in Brazil. According to Chehuen (2015), doctors and patients should discuss living wills more frequently.

Conversations regarding the judicialization of dying reached its peak among the Widows of Demétria in November 2013. The public holiday for All Souls' Day brought the theme of death and dying to the community, leading to reflections on the difficulties of dying within a biomedical regime without abandoning anthroposophy. In the week leading up to the Day of the Dead, residents of Demétria were invited to participate in a lecture given by Stella Marques, a lawyer, entitled "Death as a Friend: Legal Aspects."

The intention of the lecture was to clarify possible doubts, and to guide the community on how to proceed legally, in accordance with anthroposophical orientations, in cases of hospitalization with terminal illness, as well as in funerary rituals, and in the refusal to donate organs. Older community members participated in the event intensely; most of the audience had grey hair. The lawyer seemed to be training them for a war, and the meeting seemed to serve as an exercise for the confrontation between peasants and the windmills of biomedicine. Was it quixotic? Perhaps. Sensing the proximity of death, the lecture's audience were more interested in this inevitable conflict. Enviably, they did not appear to fear the end.

Over the course of this event, brochures were distributed that contained a theoretical discussion of themes pertaining to disease and death, including: the concept of death during the 1960s; Euthanasia, Dysthanasia, and Orthothanasia; as well as information on how to write a living will or other advance instructions allowing sick people to express their wishes for the end of their lives.

Such legal documents allow patients to refuse, in advance, medical treatments prolonging their lives artificially, blood transfusions, or even morphine in cases of cancer. The brochure, contained no bibliographical references for the concept of 
death to which Marques, the lawyer, was referring. But according to Marques, the concept of death was previously that of cardio-respiratory arrest, whereas currently, brain death is what characterizes an individual's death. It is worth noting the aesthetic care she took in selecting, for the brochure's cover, the painting Sleep and His Half-Brother Death, by the English painter John William Waterhouse, thereby referencing the myth that compares death to a profound sleep.

Rosamaria Carneiro (2015) cites an article by Rachel Menezes (2003), “Technology and Natural Death: Dying in Contemporaneity," in which the author emphasizes that, through the development of "artificial lungs," and the acceptance of "brain death," a reading of "modern death" has come to take hold, in which a dead person is controlled by machines and retains life through this mechanical connection. With this paradigmatic shift, "living well" has become socially understood to mean "living long" (CARNEIRO, 2015). The technical development of healthcare has created an environment that leaves no room for dignity, or that consigns dignity to being a secondary consideration. According to Schramm (2002), modern times have disappropriated death and separated people from a consciousness of dying, thereby resulting in a clear loss of autonomy in decision making.

\section{The question of organ donation}

On a cold winter afternoon, Ms. Melba and I met together in her small, cozy kitchen. While water boiled on the stove, warming the whole room, Mel started a conversation about how anthroposophy understands organ donation, and what it advises. In spite of the controversial nature of the spiritual science's position regarding donation, Melba was convinced that it was correct, and that individual processes of cosmic evolution must be respected and not subject to outside interference, so that beings can follow their Bildung with the organs with which they were born.

First of all, in principal you shouldn't donate anything, everyone is responsible for their health and their body, for the conservation of their body and their organs. Anthroposophy sees this as an interference in individuality: people who receive organ [transplants] have to take an absurd amount of medication so that their bodies won't reject the organs being donated, and this medication interferes with the Self, weakens the Self. In other words... all the work we do to strengthen the Self is lost. [Organ] donation interferes in that person's evolution. If a person's organ stopped, it's because there's a larger reason. Nowadays, with all of this propaganda, it seems cruel, but everyone deals with their own degree of consciousness. (Mel) 
When can we consider ourselves to have died? Melba philosophized about this and, in exposing her fears, showed herself to share the trepidation that a majority of people in Brazil feel regarding underground commerce for organs. In anthroposophy, the heart has agencies that are far from the functions attributed to it by biomedicine. Its function is not to circulate blood; instead, blood is what moves the heart, and is of singular importance to maintaining physical and biological health. As long as the heart is pumping, life exists.

The other aspect is that, if your heart stops, which is what death really is, you can only donate the cornea and, I think, the kidneys. The other organs have to be removed while the heart is still pumping, the transplant only works when organs are taken from a still-living person! After the first transplant, this idea of brain death measured by a machine was invented, so that death is no longer when the heart stops. So who can believe that it really happened? It's something that's completely manipulated, there's a terrible black market for organ sales. From my point of view, you shouldn't donate. (Mel)

In order for organ donation to occur in biomedicine, organs must be removed from the deceased person's body while blood is still flowing; in other words, before the heart has finished pumping, and before machines can no longer keep the patient breathing. Followers of anthroposophy do not recognize brain death. To them, death only occurs when the heart stops. If this has not yet taken place, organs are being removed from a living body.

Anthroposophy's guidance forbidding organ donation may appear polemical. However, a more careful examination shows a well-tuned agreement with anthroposophical cosmology. Regardless of cause, anthroposophy sees sickness and death as cures for larger, more complex questions. Donating an organ to re-establish someone's health is understood as a harmful interference in the evolutionary process of the person receiving this organ. In this sense, an act that appears benevolent would in fact be responsible for slowing that person's karma.

\section{Discussion: the mana of dying}

Carlos Rodrigues (1984, p. 99), in his book The Taboo of Death (Tabu da Morte), affirms that, instead of saying that death has power, "it would be better to say that it has mana; in other words, a general capacity to produce effects on a societal levels, and on society's symbolic systems." For Marcel Mauss “[...] le mana n'est pas simplement une force, un être, c'est encore une action, une qualité et un état. [...]On dit 
d'un être, esprit, homme, pierre ou rite, qu'il a du mana"4 (1904, p. 68). We will take this as an opportunity for further examination.

Biomedicine, like anthroposophy, has its own rituals of dying. These ritualistic practices and the discourses surrounding them manipulate the power of death, the mana in dispute. One example can be found in what dead people are offered in their "lives" after death. Rituals - both those relating to death, as well as those relating to fertility and reproduction, birth, coming of age, war, and harvest, among others reflect the values and beliefs shared by any given group, culture, or society. In every society, families and their social circles are structured in accordance with meanings shared by the larger group. Cultural references determine the care given to a dying body and its handling after death (MENEZES; GOMES, 2011).

What we are emphasizing here are the appropriation strategies of distinct cultural systems, as well as the power of death as mediated by rituals, both within anthroposophy and in biomedicine. One example of this is in the "choice" of life after death, where this "choice" depends on following the rules established by each given culture. In anthroposophy, the way that dying people confront sickness guarantees status within their community. A beautiful death is a consequence of spiritual evolution.

In his book, Rodrigues (1984, p. 103) describes multiple cultures, all of which see death's supreme power as deriving from immortality. After all, "all forms of power see themselves as eternal." In biomedicine, power is incarnate in the stillliving body, thereby giving way to the juggling act of keeping bodies alive, so as to maintain power. In anthroposophy, on the other hand, dying and death intensify an individual's power. Death is not feared as the end, because anthroposophy believes in reincarnation and in the recollection of past lives. Power is therefore established as being without limits and atemporal, beyond the material realm.

Prolonging life, whether through resuscitation, continued life support, or organ transplantation, can also be understood as a ritualized power of biomedicine that prescribes where, how, when, and in what circumstances we are allowed to die. The obligations of traditional therapists, who either cure or help dying people, have been transformed in contemporary life.

\section{Final Considerations}

Through conversations with the Widows of Demétria, we have been able to glimpse another option for dying, as well as the dispute over the control of death 
between anthroposophy and biomedicine. Thus, we must learn how to die. Is it possible to die in anthroposophy without first having gone through a Bildung? In anthroposophy, painful experiences are understood to be an opportunity for inner strengthening, forging an armor for this life or for the next. This conception of a dignifying, almost heroic death appears much more captivating than the materialistic death presented by biomedicine. Is this project of Bildung viable in other cultures?

The aesthetics of a "beautiful death" in anthroposophy does not appear to be for every living thing. Bearing the pain of terminal cancer while conscious and without morphine is too challenging for the children of biomedical analgesics. The expectation of a "beautiful death" may frustrate our sense of what is beautiful, and anthroposophy sometimes leaves us with a bitter taste in our mouths. First, why offer us a captivating answer to the torturous question that accompanies our entire lives: how will we die? According to this spiritual science, death is not so insurmountable, and this conflict seems viable. Death is no longer an enemy; perhaps it becomes a friend. But the bitter taste remains, the taste of being unable to attain the ideal of courage and determination in the task of dying. We want to die in peace, but we will always confront the noise of the conflict for mana in the ritual of dying. ${ }^{5}$

\section{References}

ABMA. Associação Brasileira de Medicina Antroposófica. Terapias Antroposóficas. Accessible at: <http://www.abmanacional.com.br/\#>. Last accessed: Dec 12, 2011.

ALVES, N. L; CASAGRANDE, M. L. Aspectos éticos, legais e suas interface sobre o morrer. Revista Científica do ITPAC, Araguaína, v.9, n. 1, fev. 2016.

AUTOR. Corpo e saúde na antroposofia: Bildung como cura. São Paulo: LiberArs, 2018.

CARNEIRO, R. A vida em suspensão: "Fale com ela" e os sentidos da morte. Interface, Comunicação, Saúde e Educação, v. 19, n. 54, p. 615-21, 2015.

CHEHUEN, N. J. A. Testamento vital: o que pensam profissionais de saúde? Revista Bioética, Brasília, v. 123, n. 3, Sept-Dec. 2015.

COMBINATO, D. S, MARTIN, S. T. F. Necessidades da vida na morte. Interface, Comunicação, Saúde e Educação, v. 21, n. 63, p. 869-80, 2017.

DADALTO, L.; TUPINAMBAÍ, U.; GRECO, D. B. Diretivas antecipadas de vontade: um modelo brasileiro. Rev. bioét., v. 21, n. 3, p. 463-76, 2013.

DUARTE, L. F. D. Indivíduo e pessoa na experiência da saúde e da doença. Ciênc. Saúde Coletiva, v.8, n. 1, p. 173-183, 2003. 
FLORIANI, C. A. Kalotanásia, antroposofia e o moderno movimento hospice: compartilhando um modelo de boa morte. In: . (Org.). No umbral da morte. São Paulo: Antroposófica, 2014.

GOLSE, B. Se laisser mourir ou vouloir mourir. Le Carnet PSY, v. 201, p. 1-1-, 2016/7.

GOMES, R. F. Abordagem espiritual antroposófica da morte e do processo de morrer. In: FLORIANI, C. A. (Org.). No umbral da morte. São Paulo: Antroposófica, 2014.

HENNEZEL, M. Mourir lês yeux ouverts. Paris: Albin Michel, 2005.

HERTZ, R. [1907]. A contribution to the study of the collective representation of death. In: . Death and the right hand. Illinois: The Free Press Glencoe, 1960.

KAMIJO, E. D; LIMA, M. V.; SCHWEDER, E. L. B. Cumprimento dos desejos do paciente por meio das diretivas antecipadas de vontade. Anais de Medicina, 2016.

KOVÁCS, M. J. O caminho da morte com dignidade no século XXI. Rev. bioét. (Impr.). 2014; 22 (1): 94-104.

LADOUCEUR, R. L’aide médicale à mourir. Canadian Family Physician, v. 63, Jan. 2017.

LYRA, E. A tecnologização da morte: filosofia, ciência e poesia. Revista Natureza Humana. São Paulo, v. 19, n. 2, p. 114-133, Jul-Dec. 2017.

MACEDO, J. L. As regras do jogo da morte encefálica. Rev. Antropol. São Paulo, v. 59, n. 2, p. 32-58, Aug. 2016.

MAUSS, M. A Expressão obrigatória dos sentimentos. In: FIGUEIRA, S. (Org.). Psicanálise e Ciências Sociais. Rio de Janeiro: Francisco Alves, 1980.

MAUSS, M.; HUBERT, H. Esquisse d'une théorie générale de la magie. L’Année sociologique, v. 7, p. 1-146, 1904.

MENEZESR.A.; GOMES, R. “Seu funeral, sua escolha”: rituais fúnebres na contemporaneidade. Revista de Antropologia. São Paulo, v. 54, n. 1, 2011.

MENEZES, R. A. A medicalização da esperança: reflexões em torno de vida, saúde/doença e morte. Amazôn., Rev. Antropol., v. 5, n. 2, p. 478-498, 2013.

MENEZES, R. A. Em busca da boa morte: antropologia dos cuidados paliativos. Rio de Janeiro: Garamond, 2004.

MENEZES, R. A. Tecnologia e morte natural: o morrer na contemporaneidade. Physis. Rio de Janeiro, v. 13, n.2, p. 129-47, 2003.

PACHECO, B.; CRIPPA, A.; OLIVEIRA, P. O. Testamento vital: a proteção da autonomia de vontade do paciente em casos de doenças terminais. Rev. Sorbi, v. 4, n. 1, p. 58-78, 2016.

RODRIGUES, J. C. Tabu da morte. Rio de Janeiro: Editora Fiocruz; 1984. 
SCHRAMM, F. R. A questão da definição da morte, na eutanásia e no suicídio assistido. Mundo Saúde, v. 26, n. 1, p. 178-83, 2002.

SILVA, R. C. F.; HORTALE, V. A. Cuidados paliativos oncológicos: elementos para o debate de diretrizes nesta área. Cadernos de Saúde Pública. Rio de Janeiro, v. 22, n. 10, p. 2055-66, 2006.

SIMMEL, Georg. Estúdios sobre las formas de socialización. Revista de Occidente. Madrid, v. 1, p. 265, 1977. p. 265.

STEINER, R. Doença e cura. São Paulo: Associação Brasileira de Medicina Antroposófica, 1998.

TEIXEIRA, A. L. Gestôes de vida e morte: um olhar sobre o morrer no contemporâneo. Ayvu, Rev. Psicol., v. 2, n. 2, p. 150-171, 2016.

THOMAS, Louis-Vincent. Antropología de la muerte. México: Fondo de Cultura Económica, 1993.

VERNANT, J. P. La belle mort ou le cadavre outragé. In: . L'individu, la mort et l'histoire: soi-même et l'autre en Grèce Ancienne. Paris: Gallimard, 1989.

WIEBE, E.; GREEN, S.; SCHIFF, B. Enseigner l'aide médicale à mourir aux residents. Canadian Family Physician, v. 64, April 2018.

\section{Notes}

${ }^{1}$ This text is based on the results of ethnographic research for a doctoral dissertation carried out in 2016 in anthroposophical communities and clinics in Brazil and Switzerland. The project was approved by Brazil's Ethical Committee in 2013, and it is registered under the Ethical Consideration Presentation Certificate (CAAE) number 11991512.3.0000.5505, under the title "Ethnographic Study of Health in Anthroposophy: Bildung as Cure." The research was funded by Brazil's Coordination for the Improvement of Higher Education (CAPES) in 2014, 2015, and 2016.

${ }^{2}$ A woman from the state of Rio Grande do Sul, in southern Brazil. (T.N.)

${ }^{3}$ According to Brazil's Anthroposophical Bookstore (Livraria Antroposófica) site, Christology is one of the central themes of anthroposophy's cosmovision, which is essentially Christian.

${ }^{4}$ Based on Bastos' translation to Portuguese: "Mana is not simply a force [or] a being; it is also an action, a quality, and a state [of being]...It can be said that a being, a spirit, a man, a stone, or a rite has mana." (T.N.)

${ }^{5}$ R. L. de Bastos: research, article elaboration, revision, correction, and submission. R. Matsue: research, article elaboration, revision, and correction. P.P.G. Pereira: supervision of and participation in research, article elaboration, revision, and correction. 


\section{Abstract}

A morte e o morrer entre a antroposofia e a biomedicina

A morte e o morrer suscitam continuamente o debate sobre as fronteiras, as regras e a disputa pela legitimidade dos distintos significados que envolvem os processos de finalização da vida. Este artigo busca abordar, especialmente, os conflitos que ocorrem entre o sistema terapêutico antroposófico e a biomedicina no Brasil. As reflexôes se dão com base na etnografia multissituada realizada entre os anos 2012 e 2016 que se debruçou sobre a concepção de cura na antroposofia em três comunidades, duas no Brasil e uma na Suíça. Nesse percurso, fomos levados pela experiência etnográfica às elaboraçóes sobre a morte e o morrer das viúvas da Demétria, uma das comunidades antroposóficas investigadas. Demétria é um bairro rural no interior do estado de São Paulo, na cidade de Botucatu, composto na sua maioria por mulheres, europeias e brasileiras, que convivem e partilham de um estilo de vida que reelabora o ethos da morte como um projeto estético de Bildung que difere da concepção do processo de morte na biomedicina.

Palavras-chave: morte, antroposofia, biomedicina, Bildung, estética. 